\title{
Analysis of obese patients' medical conditions in the pre and postoperative periods of bariatric surgery
}

\section{Análise das condições clínicas de pessoas obesas em período pré e pós-operatório de cirurgia bariátrica}

\author{
Anderson da Silva Ręgo1; Aline Zulin²; Sandro Scolarl²; Sônia Silva Marcon¹; Cremilde Aparecida Trindade Radovanovic¹.
}

\author{
A B S T R A C T
}

\begin{abstract}
Objective: to compare the clinical conditions of obese patients in the pre and postoperative period of bariatric surgery. Methods: we carried out a descriptive, retrospective, quantitative study by consulting the charts of 134 patients who underwent bariatric surgery in the period from 2009 to 2014. We collected the data between September and November 2015. We performed a descriptive statistical analysis and comparative analysis of anthropometric, metabolic, biochemical and clinical variables, considering six months before and after surgery. Results: the majority of the patients were female (91.8\%), with a higher prevalence (35\%) in the age group 18 -29 years old, complete high-school education (65.6\%) and grade III obesity (60.4\%). Six months after surgery, weight and lipid profile reduction were significant in both genders, but the impact on biochemical, anthropometric, metabolic and clinical parameters was significant only in female subjects, with a reduction in morbidities associated with obesity, such as arterial hypertension, diabetes mellitus, dyslipidemia and metabolic syndrome and in the use of drugs to control them. Conclusion: bariatric surgery was effective in weight loss, with improvements in anthropometric, metabolic and biochemical parameters and in the reduction of morbidities associated with obesity.
\end{abstract}

Keywords: Obesity. Bariatric surgery. Nutrition Assessment.

\section{INTRODUCTION}

$\mathrm{T}$ he demographic, epidemiological and socioeconomic transition, and its consequent changes in life and alimentary habits, are determinant factors for the obesity increase in the population, mainly in developed and highly industrialized countries. Obesity, in turn, triggers social and psychological damages such as depression, low self-esteem and social isolation, with negative effects on quality of life ${ }^{1,2}$.

The Brazilian Ministry of Health estimated that in $2014,52.5 \%$ of the country's population was overweight, a considerable increase of $9.5 \%$ in the index compared with the year $2006^{3}$. It emphasized that, of the people with excess weight in the age group between 35 and 64 years, 17.9\% are females, are already obese, and with low schooling. Obesity favors the increase of chronic diseases, such as systemic arterial hypertension, diabetes mellitus and cancer, responsible for $72 \%$ of deaths in the country ${ }^{3}$.

Bariatric surgery is a viable option for the significant and rapid weight loss and also as a strategy to maintain metabolic rates, and even for the reduction and remission of obesity-related chronic diseases ${ }^{4}$. Surgical indication must occur after a rigorous multiprofessional evaluation, with assessment of nutritional status, anthropometric measures, and psychological conditions to follow medical and nutritional recommendations after the procedure. This is because the success of surgical treatment essentially depends on the emotional balance and changes in the individual's lifestyle $e^{4,5}$.

Bariatric surgery has been innovating over the years and its technique has become less and less invasive, providing fast and better recovery ${ }^{6}$. It allows weight loss of about $40 \%$ of the initial weight in a period of six to 12 months, generating large changes in daily habits and attributions, whether in a social or family environment and also in body image ${ }^{7,8}$.

In this aspect, knowing the benefits of the surgical procedure, such as weight loss and the improvement of the metabolic parameters, is relevant for proposing actions that can avoid complications, promoting self-care and improving the quality of life ${ }^{6}$. Thus, the objective of this study was to compare the

1 - State University of Maringá, Post-Graduate Program in Nursing, Maringá, Parana State, Brazil. 2 - Dr. Sandro Scolari Surgery Institute, Maringá, Parana State, Brazil. 
clinical conditions of obese people in the pre and postoperative period of bariatric surgery.

\section{METHODS}

This is a descriptive, retrospective, quantitative study conducted at a Bariatric Surgery Institute that performs on average eight bariatric surgeries per month, by the same medical professional, located in the city of Maringá - PR.

We collected data from September to December 2015, based on the medical records of individuals who underwent bariatric surgery in the period from 2009 to 2014. For this purpose, was used a script consisting of the following variables: a) nutritional status (weight, height, body mass index $\mathrm{BMI}) ; \mathrm{b})$ presence of associated morbidities (systemic arterial hypertension - SAH, diabetes mellitus - DM, metabolic syndrome - MS, dyslipidemia, hepatic steatosis and cardiopathies); c) biochemical parameters: fasting glycemia, erythrocytes, total cholesterol, LDL and HDL cholesterol, triglycerides, transaminases (AST, ALT), alkaline phosphatase and gamma-gt-GGT); and d) use of medications. All collected variables related to the pre and postoperative periods.

We defined as eligible for the study every patient whose charts contained data records of the period of six months before to six months after surgery. Thus, we included 134 patients.

We used the recommendation of the Brazilian Society of Cardiology, which considers the parameters of NCEP-ATP III, to identify the presence of metabolic syndrome (MS) in the combination of the following components: high blood pressure or use of antihypertensives, high values of triglycerides and cholesterol, abdominal circumference $>102 \mathrm{~cm}$ for men and $>88 \mathrm{~cm}$ for women and high fasting glucose or use of hypoglycemic agents 9 .

Table 1. Socio-demographic data of patients undergoing bariatric surgery.

\begin{tabular}{|c|c|c|c|c|c|c|}
\hline & \multicolumn{2}{|c|}{ Male } & \multicolumn{2}{|c|}{ Female } & \multicolumn{2}{|c|}{ Total } \\
\hline & $\mathrm{N}$ & $\%$ & $\mathrm{~N}$ & $\%$ & $\mathrm{~N}$ & $\%$ \\
\hline \multicolumn{7}{|l|}{ Age } \\
\hline 18 to 29 years & 2 & 18.2 & 45 & 36.5 & 47 & 35.0 \\
\hline 30 to 39 years & 3 & 27.3 & 40 & 32.6 & 43 & 32.1 \\
\hline 40 to 49 years & 3 & 27.3 & 25 & 20.3 & 28 & 20.9 \\
\hline 50 to 59 years & 2 & 18.2 & 12 & 9.8 & 14 & 10.5 \\
\hline$\geq 60$ years & 1 & 9.1 & 1 & 0.8 & 2 & 1.5 \\
\hline \multicolumn{7}{|l|}{ Study years } \\
\hline Illiterate & - & - & 2 & 1.6 & 2 & 1.5 \\
\hline Junior-high School & 2 & 18.2 & 6 & 4.8 & 8 & 6.0 \\
\hline High School & 2 & 18.2 & 86 & 70.0 & 88 & 65.6 \\
\hline College Education & 7 & 63.6 & 29 & 23.6 & 36 & 26.9 \\
\hline \multicolumn{7}{|l|}{ Degree of Obesity } \\
\hline Grade II & 3 & 27.3 & 50 & 40.7 & 53 & 39.6 \\
\hline Grade III & 8 & 72.7 & 73 & 59.3 & 81 & 60.4 \\
\hline \multicolumn{7}{|l|}{ Type of surgery } \\
\hline Gastric Sleeve & 11 & 100 & 115 & 93.5 & 126 & 94.1 \\
\hline Gastric Bypass & - & - & 8 & 6.5 & 8 & 5.9 \\
\hline
\end{tabular}

Source: Maringá Bariatric Surgery Institute, 2015. 
Table 2. Comparison of obesity-associated morbidities in the pre and postoperative periods of Bariatric Surgery.

\begin{tabular}{|c|c|c|c|c|c|c|c|c|c|c|}
\hline \multirow{3}{*}{ Associated Morbidities } & \multicolumn{4}{|c|}{ Male } & \multicolumn{6}{|c|}{ Female } \\
\hline & \multicolumn{2}{|c|}{ Preoperative } & \multicolumn{2}{|c|}{ Postoperative } & \multirow[b]{2}{*}{$p^{*}$} & \multicolumn{2}{|c|}{ Preoperative } & \multicolumn{2}{|c|}{ Postoperative } & \multirow[b]{2}{*}{$p^{*}$} \\
\hline & $\mathrm{N}$ & $\%$ & $\mathrm{~N}$ & $\%$ & & $\mathrm{~N}$ & $\%$ & $\mathrm{~N}$ & $\%$ & \\
\hline \multicolumn{11}{|l|}{ Arterial Hypertension } \\
\hline Yes & 6 & 54.5 & 3 & 27.3 & \multirow{2}{*}{0.121} & 26 & 21.2 & 16 & 13 & \multirow{2}{*}{0.000} \\
\hline No & 5 & 45.5 & 8 & 72.7 & & 97 & 78.8 & 107 & 87 & \\
\hline \multicolumn{11}{|l|}{ Diabetes Mellitus } \\
\hline Yes & 2 & 18.2 & 2 & 18.2 & \multirow{2}{*}{0.345} & 21 & 17.1 & 4 & 3.3 & \multirow{2}{*}{0.001} \\
\hline No & 9 & 81.8 & 9 & 81.8 & & 102 & 82.9 & 119 & 96.7 & \\
\hline \multicolumn{11}{|l|}{ Dyslipidemia } \\
\hline Yes & 6 & 54.5 & 1 & 9.1 & \multirow{2}{*}{0.545} & 47 & 35.8 & 5 & 4.1 & \multirow{2}{*}{0.005} \\
\hline No & 5 & 45.5 & 10 & 90.9 & & 79 & 64.2 & 118 & 95.9 & \\
\hline \multicolumn{11}{|l|}{ Hepatic Steatosis } \\
\hline Yes & 6 & 54.5 & 0 & 0 & & 52 & 42.3 & - & - & \multirow{2}{*}{-} \\
\hline No & 5 & 45.5 & 11 & 100 & & 71 & 57.7 & 123 & 100 & \\
\hline \multicolumn{11}{|l|}{ Metabolic Syndrome } \\
\hline Yes & 11 & 100 & 5 & 45.5 & & 47 & 38.2 & 17 & 13.8 & \multirow{2}{*}{0.000} \\
\hline No & - & - & 6 & 54.5 & & 76 & 61.8 & 106 & 86.2 & \\
\hline \multicolumn{11}{|l|}{ Use of Medications } \\
\hline Yes & 8 & 72.7 & 4 & 36.4 & \multirow{2}{*}{0.212} & 79 & 64.2 & 14 & 11.3 & \multirow[t]{2}{*}{0.031} \\
\hline No & 3 & 63.3 & 7 & 63.3 & & 44 & 35.8 & 109 & 88.7 & \\
\hline
\end{tabular}

Source: Maringá Bariatric Surgery Institute, 2015. * Pearson's Chi-square test.

To classify obesity according to BMI, we adopted the criteria proposed by the World Health Organization ${ }^{10,11}$, recommended by the Brazilian Society of Endocrinology and Metabolism² ${ }^{12}$. According to this criterion, nutritional status is classified as low weight (BMI <18.5), eutrophic (BMl between 18.5 and $24.9 \mathrm{~kg} / \mathrm{m}^{2}$ ), overweight (BMI $25-29.9 \mathrm{~kg} / \mathrm{m}^{2}$ ), obesity grade I (BMI $30-34.9 \mathrm{~kg} / \mathrm{m}^{2}$ ), obesity grade I| (BMI $\left.35-39.9 \mathrm{~kg} / \mathrm{m}^{2}\right)$ and obesity grade III (BMI $\left.>40 \mathrm{~kg} / \mathrm{m}^{2}\right)$.

We entered the data into the Microsoft Excel $2010 \AA$ software and, after conference, we transferred them to the IBM SPSS $®$ software, version 20.0. For all statistical tests, we set significance at $5 \%(p \leq 0.05)$. We presented the descriptive analysis in absolute frequency and percentage. We used the Shapiro-Wilk test to verify the variables' normality.

When the normality assumption was verified, we used the paired " $t$ " test to compare the mean of the anthropometric and biochemical variables in the pre and postoperative period. To measure the association between the explanatory and outcome variables, we used the Pearson chi-square test.

We developed the study in accordance with the ethical precepts disciplined by Resolution 466/12 of the National Health Council and the research project was approved by the Standing Committee on Ethics in Research with Humans (COPEP) of the State University of Maringá (opinion no. 1246542).

\section{RESULTS}

Of the 134 patients evaluated, the majority were female (91.8\%). Among them, there was a higher prevalence in the age group of 18 to 29 years (36.5\%), complete high-school education (70\%) and more than half had grade III obesity (59.3\%). Men were more prevalent in the $30-49$ age group (54.6\%), the majority (63.6\%) had college education and grade III obesity 
Table 3. Comparison of nutritional status in the pre and postoperative periods of Bariatric Surgery.

\begin{tabular}{|c|c|c|c|c|c|c|c|c|}
\hline & \multicolumn{4}{|c|}{ Male } & \multicolumn{4}{|c|}{ Female } \\
\hline & \multicolumn{2}{|c|}{ Preoperative } & \multicolumn{2}{|c|}{ Postoperative } & \multicolumn{2}{|c|}{ Preoperative } & \multicolumn{2}{|c|}{ Postoperative } \\
\hline & $\mathrm{N}$ & $\%$ & $\mathrm{~N}$ & $\%$ & $\mathrm{~N}$ & $\%$ & $\mathrm{~N}$ & $\%$ \\
\hline Eutrophic & & & 1 & 9.1 & & & 21 & 17.0 \\
\hline Overweight & & & 7 & 63.6 & & & 61 & 49.6 \\
\hline Obese Grade I & & & 3 & 27.3 & & & 29 & 23.5 \\
\hline Obese Grade ॥ & 3 & 27.3 & & & 50 & 40.6 & 12 & 9.9 \\
\hline Obese Grade III & 8 & 72.7 & & & 73 & 59.4 & & \\
\hline
\end{tabular}

Source: Maringá Bariatric Surgery Institute, 2015.

(72.7\%) (Table 1). The most used surgical technique was the Gastric Sleeve, in $94.1 \%$ of the patients.

Table 2 shows that the reduction of arterial hypertension, diabetes mellitus, dyslipidemia, metabolic syndrome and use of medications in the postoperative period were only significant for the female patients.

Table 3 presents information related to nutritional status. We observed that grade III obesity was more prevalent among men (72.7\%). After surgery, a large part (63.6\%) passed into the overweight class. Among women, $59.4 \%$ had grade III obesity and in the postoperative period, $49.6 \%$ became overweight.

The results of the comparison between the means of the anthropometric variables in the pre and postoperative periods show reduction in both weight and BMI, with significant value in both genders. As for the metabolic parameters, there was a significant increase in the HDL levels in female patients. The values of the biochemical parameters of total proteins, ferritin, AST, ALT and GGT showed a significant reduction in both genders. The values of $L D L$, total cholesterol and triglycerides also showed a significant reduction in both genders. Erythrocytes, albumin, and alkaline phosphatase presented value changes in the female patients' results (Table 4).

\section{DISCUSSION}

The majority of patients undergoing bariatric surgery in our study were female, which corroborates with results of other studies performed in different regions of the country 2,13-15.
It is noteworthy that six months before surgery, most of the individuals had grade III obesity. The weight loss and the change in obesity classification described in table 3 were also verified in a study that adopted the same parameters and identified that many patients classified as high-grade obese before the surgical procedure presented lower grades and even normal weight six months after surgery ${ }^{16}$.

The comorbidities associated with obesity improved between the bariatric surgery pre and postoperative periods. Dyslipidemia, present in most patients of both genders in this study, had a significant reduction in females, which also showed a significant decrease in Total and LDL cholesterol and triglycerides, and an increase in HDL cholesterol. Bariatric surgery allowed changes in eating habits, characterized by the ingestion of foods in small amounts, with lower caloric value and allowed weight reduction and adoption of healthy habits. Studies have shown that reducing dyslipidemia reduces the risk of cardiovascular diseases ${ }^{17,18}$.

We also observed reduction in the percentages of SAH and DM. These results are similar to those of other studies whose results point to a gradual reduction of weight and improvement in metabolism, with a decrease in hypertension and $\mathrm{DM}^{19}$. As observed by other authors, there was also a reduction in the use of medications for treatment and control of comorbidities associated with obesity ${ }^{20,21}$. Ghiassi et al. ${ }^{21}$ found that bariatric surgery was beneficial not only for the patient's general health, but also for the reduction of costs resulting from the purchase of medications and activities related to the 
Table 4: Comparison of the metabolic, biochemical and anthropometric parameters of obese patients in the pre and postoperative periods of Bariatric Surgery.

\begin{tabular}{|c|c|c|c|c|c|c|}
\hline \multirow[b]{2}{*}{ Parameters } & \multicolumn{3}{|c|}{ Male } & \multicolumn{3}{|c|}{ Female } \\
\hline & $\begin{array}{c}\text { Preoperative } \\
\text { Mean } \pm \text { SD ** }\end{array}$ & $\begin{array}{c}\text { Postoperative } \\
\text { Mean } \pm \text { SD }\end{array}$ & $p^{*}$ & $\begin{array}{c}\text { Preoperative } \\
\text { Mean } \pm \text { SD }\end{array}$ & $\begin{array}{c}\text { Postoperative } \\
\text { Mean } \pm \text { SD }\end{array}$ & $p^{*}$ \\
\hline \multicolumn{7}{|l|}{ Anthropometric } \\
\hline Weight (kg) & $116.1 \pm 18.0$ & $81.4 \pm 14.3$ & 0.000 & $107.1 \pm 15.6$ & $76.2 \pm 14.2$ & 0.000 \\
\hline BMI $\left(\mathrm{kg} / \mathrm{m}^{2}\right)$ & $39.4 \pm 2.5$ & $27.5 \pm 2.4$ & 0.000 & $40.6 \pm 3.7$ & $28.4 \pm 4.0$ & 0.000 \\
\hline \multicolumn{7}{|l|}{ Metabolic } \\
\hline $\mathrm{HDL}(\mathrm{mg} / \mathrm{dl})$ & $52.8 \pm 32.1$ & $56.8 \pm 10.3$ & 0.667 & $53.1 \pm 19$ & $57.8 \pm 14.9$ & 0.001 \\
\hline LDL (mg/dl) & $114.5 \pm 31.8$ & $96.1 \pm 29.0$ & 0.036 & $114.5 \pm 31.7$ & $107.4 \pm 32.6$ & 0.008 \\
\hline TC (mg/dl) & $196.6 \pm 35.0$ & $168.9 \pm 29.2$ & 0.018 & $195.8 \pm 36.5$ & $186.3 \pm 33.2$ & 0.006 \\
\hline TG (mg/dl) & $168.1 \pm 82.7$ & $97.2 \pm 57.8$ & 0.009 & $150 \pm 70$ & $110.451 .7 \pm$ & 0.000 \\
\hline Fasting glucose (mg/dl) & $120.9 \pm 31.9$ & $91.5 \pm 17.4$ & 0.001 & $118.6 \pm 131.9$ & $85.5 \pm 10.8$ & 0.006 \\
\hline \multicolumn{7}{|l|}{ Biochemical } \\
\hline Red blood cells (Mi/mm³) & $4.79 \pm 0.46$ & $4.54 \pm 0.14$ & 0.052 & $4.62 \pm 0.38$ & $4.34 \pm 0.49$ & 0.000 \\
\hline Total protein $(\mathrm{g} / \mathrm{dl})$ & $7.4 \pm 0.5$ & $6.9 \pm 0.6$ & 0.013 & $7.7 \pm 5.6$ & $6.8 \pm 0.6$ & 0.09 \\
\hline Albumin (g/dl) & $4.2 \pm 0.2$ & $4.2 \pm 0.4$ & 0.933 & $4.1 \pm 0.4$ & $4.0 \pm 0.3$ & 0.033 \\
\hline Serum iron (ug/dl) & $84.2 \pm 30.3$ & $85.41 \pm 33.10$ & 0.868 & $91.3 \pm 34.7$ & $89.5 \pm 31.2$ & 0.379 \\
\hline Ferritin (ng/ml) & $293.6 \pm 168.0$ & $210.7 \pm 139.7$ & 0.017 & $142.8 \pm 114.3$ & $118.3 \pm 82.5$ & 0.002 \\
\hline Vit. B12 (pg/ml) & $404.9121 .9 \pm$ & $369.0 \pm 212.7$ & 0.487 & $358.3 \pm 247.8$ & $322.9 \pm 91.5$ & 0.117 \\
\hline AST (U/l) & $23.7 \pm 6.9$ & $18.3 \pm 4.1$ & 0.026 & $26.2 \pm 18.6$ & $21.4 \pm 15.7$ & 0.000 \\
\hline ALT (U/I) & $33.2 \pm 16.3$ & $19.2 \pm 6.2$ & 0.031 & $29.6 \pm 24$ & $21.3 \pm 9.7$ & 0.000 \\
\hline Alkaline Phosphat. (U/l) & $70.1 \pm 27.3$ & $59.6 \pm 23.8$ & 0.069 & $76.6 \pm 19.4$ & $65.5 \pm 18.6$ & 0.000 \\
\hline Gamma-GT (U/l) & $36.4 \pm 18.6$ & $21.5 \pm 11.1$ & 0.027 & $41.5 \pm 55.8$ & $25.6 \pm 20.3$ & 0.001 \\
\hline
\end{tabular}

Source: Maringá Bariatric Surgery Institute, 2015. * Paired t test $(p<0.05)$; ** Standard Deviation; TC: Total cholesterol; TG: Triglycerides.

control of comorbidities. Others, however, found that although there is a reduction in the use of drugs for treatment and control of the main diseases associated with obesity, there is an increase in the use of other medications, mainly nutritional supplements ${ }^{20}$.

In Brazil, we found no studies addressing the reduction of costs related to the purchase of medicines after bariatric surgery. One study, however, has addressed the reduction in drug use to control weight regain ${ }^{22}$. We believe that it is important to quantify the economic impact of non-use of disease control drugs, especially for high blood pressure and diabetes mellitus, most prevalent chronic diseases, and responsible for most causes of death, in the country ${ }^{23}$.

Hepatic steatosis, identified by elevated levels of AST, ALT, GGT and biopsy specimens, also showed reduction after bariatric surgery. Other authors also observed a $46.6 \%$ reduction in steatosis among the individuals studied ${ }^{24-27}$. A meta-analysis carried out in the United Kingdom indicated a reduction of liver enzymes, considered markers of liver function and liver damage, statistically associated with the reduction of hepatic steatosis shortly after surgery ${ }^{25}$. The reduction of hepatic steatosis is due to changes in food habits. On the other hand, the reduction of dietary intake due to gastric reduction, in addition to causing weight loss, generates nutritional deficiencies, especially in the first year after surgery ${ }^{28}$.

In our study, the results pointed to a significant reduction in the number of red blood cells in women due to the reduction of gastric volume and the production of gastric juice, responsible for the initial iron metabolism. With the stomach reduction, the digestion of food becomes more time consuming, 
especially those rich in protein and fiber, which are also rich in iron, which causes satiety, decreasing the number and quantity of food intake ${ }^{29}$. The values of ferritin also showed a significant reduction.

We should note that the not significant reduction in vitamin B12 and serum iron levels in both genders may be due to the short postoperative follow- up, a period in which there is still a large reserve of micronutrients ${ }^{30}$.

Our study demonstrated that bariatric surgery was effective in weight loss, with improvement of anthropometric, metabolic and biochemical parameters, and in the reduction of morbidities associated with obesity.

\title{
R E S U M O
}

\begin{abstract}
Objetivo: comparar as condições clínicas de pacientes obesos em período pré e pós-operatório de cirurgia bariátrica. Método: estudo descritivo, retrospectivo, de abordagem quantitativa, por meio de consulta ao prontuário de 134 pacientes submetidos à cirurgia bariátrica no período de 2009 a 2014. Os dados foram coletados entre os meses de setembro e novembro de 2015 . Foi realizada análise estatística descritiva e comparativa das variáveis antropométricas, metabólicas, bioquímicas e clínicas, considerando seis meses antes e após a cirurgia. Resultados: a maioria dos pacientes era do sexo feminino $(91,8 \%)$, com maior prevalência (35\%) na faixa etária de 18 aos 29 anos, com ensino médio completo $(65,6 \%)$ e obesidade grau III (60,4\%). Seis meses após a cirurgia, a redução do peso e o perfil lipídico foram significativos em ambos os sexos, mas o impacto nos parâmetros bioquímicos, antropométricos, metabólicos e clínicos foi significativo apenas nos indivíduos do sexo feminino, com redução das morbidades associadas à obesidade como hipertensão arterial, diabetes mellitus, dislipidemia e síndrome metabólica e na utilização de medicamentos. Conclusão: a cirurgia bariátrica foi eficaz na perda ponderal de peso, com melhoras nos parâmetros antropométricos, metabólicos e bioquímicos e na redução de morbidades associadas à obesidade.
\end{abstract}

Descritores: Obesidade. Cirurgia bariátrica. Avaliação Nutricional.

\section{REFERENCES}

1. Camargo APPM, Barros Filho AA, Antonio MARGM, Giglio JS. A não percepção da obesidade pode ser um obstáculo no papel das mães de cuidar de seus filhos. Ciênc saúde coletiva, 2013;18(2):323-33.

2. Oliveira DM, Meregui MAB, Jesus MCP. A decisão da mulher obesa pela cirurgia bariátrica à luz da fenomenologia social. Rev esc enferm USP. 2014;48(6):970-6.

3. Brasil. Ministério da Saúde. Secretaria de Vigilância em Saúde. Departamento de Vigilância de Doenças e Agravos não Transmissíveis e Promoção da Saúde. Vigitel Brasil 2014: vigilância de fatores de risco e proteção para doenças crônicas por inquérito telefônico / Ministério da Saúde, Secretaria de Vigilância em Saúde, Departamento de Vigilância de Doenças e Agravos não Transmissíveis e Promoção da Saúde. Brasília: Ministério da Saúde, 2015.

4. Marcelino LF, Patrício ZM. A complexidade da obesidade e o processo de viver após a cirurgia bariátrica: uma questão de saúde coletiva. Ciênc saúde coletiva. 2011;16(12):4767-76.

5. Prevedello CF, Colpo E, Mayer ET, Copetti H. Análise do impacto da cirurgia bariátrica em uma po- pulação do centro do estado do Rio Grande do Sul utilizando o método BAROS. Arq Gastroenterol. 2009;46(3):199-203.

6. Barros LM, Frota NM, Moreira RAN, Araújo TM, Caetano JA. Avaliação dos resultados da cirurgia bariátrica. Rev Gaúcha Enferm. 2015;36(1):21-7.

7. Miranda NPN, Conti MA, Bastos RR, Laus MF, Almeida SS, Ferreira MEC. Imagem corporal de adolescentes de cidades rurais. Ciênc saúde coletiva. 2014;19(6):1791-801.

8. Nassif PAN, Lopes AD, Lopes GL, Martins PR, Pedri LE, Varaschim $M$, et al. Alterações nos parâmetros pré e pós-operatórios de pacientes com síndrome metabólica, submetidos a Bypass gastrointestinal em $Y$ de Roux. ABCD, arq bras cir dig. 2009;22(3):165-70.

9. Sociedade Brasileira de Cardiologia. Diretrizes da Sociedade Brasileira de Cardiologia: pocket book 2013-2015. Coordenação Luiz Carlos Bodanese. 7ạ ed rev. São Paulo:OMNIFARMA; 2015.

10. Obesity: preventing and managing the global epidemic. Report of a who Consultation. World Health Organ Tech Rep Ser 2000; 894:i-xii, 1-253.

11. World Health Organization. Obesity: Preventing and Managing the Global Epidemic; Report of a 
WHO Consultation. Geneve: World Health Organization; 2000 [Technical Report Series No. 894].

12. Associação Brasileira para o Estudo da Obesidade e da Síndrome Metabólica - ABESO. Diretrizes brasileiras de obesidade [online]. ABESO; 20092010. Disponível em: http://www.abeso.org.br/.

13. Mariano MLL, Paula MAB, Bassi DG, Paula PR. Cirurgia bariátrica: repercussões na sexualidade da pessoa obesa. Rev Col Bras Cir. 2014; 41(6): 412-20.

14. Silveira-Júnior $S$, Albuquerque MM, Nascimento RR, Rosa LS, Hygidio DA, Zapelini RM. Nutritional repercussions in patients submitted to bariatric surgery. $A B C D$, arq bras cir dig. 2015;28(1):48-52.

15. Silva PRB, Souza MR, Silva EM, Silva SA. Nutritional status and life quality in patients undergoing bariatric surgery. $A B C D$, arq bras cir dig. 2014;27(Suppl 1):35-8.

16. Silva MAM, Riveira IR, Barbosa EMW, Crispim MAC, Farias GC, Fontan AJA, et al. Frequência de fatores de risco cardiovascular antes e 6 e 12 meses após gastroplastia. Rev Assoc Med Bras. 2013;59(4):381-6.

17. Garcez MR, Pereira JL, Fontanelli MM, Marchioni DML, Fisberg RM. Prevalência de dislipidemia segundo estado nutricional em amostra representativa de São Paulo. Arq Bras Cardiol. 2014;103(6):476-84.

18. Carswell KA, Belgaumkar AP, Amiel SA, Patel AG. A systematic review and meta-analysis of the effect of gastric bypass surgery on plasma lipid levels. Obes Surg. 2016;26(4):843-55.

19. Vargas $V$, Allende $H$, Lecube $A$, Salcedo $M T$, Baena-Fustegueras JA, Fort JM, et al. Surgically induced weight loss by gastric bypass improves non alcoholic fatty liver disease in morbid obese patients. World J Hepatol. 2012;4(12):382-8.

20. Crémieux PY, Ledoux S, Clerici C, Cremieux F, Buessing $M$. The impact of bariatric surgery on comorbidities and medication use among obese patients. Obes Surg. 2010;20(7):861-70.

21. Ghiassi S, Morton J, Bellatorre N, Eisenberg D. Short-term medication cost savings for treating hypertension and diabetes after gastric bypass.
Surg Obes Relat Dis. 2012;8(3):269-74.

22. Pajecki D, Halpern A, Cercato C, Mancini M, Cleva $R$, Santo MA. Tratamento de curto prazo com liraglutide no reganho de peso após cirurgia bariátrica. Rev Col Bras Cir. 2012;40(3):191-5.

23. Brasil. Ministério da Saúde. Secretaria de Vigilância em Saúde. Departamento de Análise de Situação de Saúde. Plano de ações estratégicas para o enfrentamento das doenças crônicas não transmissíveis (DCNT) no Brasil 2011-2022 / Ministério da Saúde. Secretaria de Vigilância em Saúde. Departamento de Análise de Situação de Saúde. Brasília: Ministério da Saúde, 2011.

24. Silva LGO, Manso JEF, Silva RARN, Pereira SE, Saboya Sobrinho CJ, Rangel CW. Relação entre o estado nutricional de vitamina $A$ e a regressão da esteatose hepática após gastroplastia em Y-de-Roux para tratamento da obesidade classe III. ABCD, arq bras cir dig. 2012;25(4):250-6.

25. Bower G, Toma T, Harling L, Jiao LR, Efthimiou $E$, Darzi $A$, et al. Bariatric surgery and non-alcoholic fatty liver disease: a systematic review of liver biochemistry and histology. Obes Surg. 2015;25(12):2280-9.

26. Tai CM, Huang CK, Hwang JC, Chiang $H$, Chang $C Y$, Lee $C T$, et al. Improvement of nonalcoholic fatty liver after bariatric surgery in morbidly obese Chinese patients. Obes Surg. 2012;22(7):1016-21.

27. Caiazzo R, Lassailly G, Leteurtre E, Baud G, Verkin$d t H$, Raverdy $V$, et al. Roux-en- $Y$ gastric bypass versus adjustable gastric banding to reduce nonalcoholic fatty liver disease: a 5-year controlled longitudinal study. Ann Surg. 2014;260(5):893-8; discussion 898-9.

28. Ramos NMCPJ, Magno FCCM, Cohen L, Rosado EL, Carneiro JRI. Perda ponderal e presença de anemias carenciais em pacientes submetidos à bypass gástrico em Y-de-Roux em uso de suplementação de vitaminas e minerais. $A B C D$, arq bras cir dig. 2015;28(1):44-7.

29. Leiro LS, Melendez-Araújo MS. Adequação de micronutrientes da dieta de mulheres após um ano de bypass gástrico. ABCD, arq bras cir dig. 2014;27(Suppl 1):S21-5. 
30. Carvalho IR, Loscalzo IT, Freitas MFB, Jordão RE, Friano TC. Incidência da deficiência de vitamina B12 em pacientes submetidos à cirurgia bariátrica pela técnica Fobi-Capela (Y-de-Roux). ABCD, arq bras cir dig. 2012;25(1):36-40.
Received in: 22/09/2016

Accepted for publication: 09/12/2016

Conflict of interest: none.

Source of funding: none.

\section{Mailing address:}

Anderson da Silva Rêgo

E-mail: anderson0788@hotmail.com andersondsre@gmail.com 